\title{
I dig therefore we are: community archaeology, place-based social identity, and intergroup relations within local communities
}

\begin{abstract}
Community involvement in archaeological digs aims to reconnect people with the history and heritage of where they live. This paper applies social psychological theories to understand how community archaeological projects create opportunities for place-based social identity and positive inter-group relations. Focus groups were conducted across five areas of Greater Manchester (UK) with 24 participants who volunteered for Dig Greater Manchester, a community archaeology initiative. The focus groups aimed to understand how experiences of participating in digs and exploring local heritage modified, strengthened or initiated identification with place and community; thus moving from individual levels to social levels of identity. The findings offer insight as to the ways in which people make sense of their own and others' - place-based social identities as a result of participating in community archaeological digs.
\end{abstract}

Keywords: community archaeology; place identity; intergroup relations; heritage; community cohesion 


\section{Introduction}

The construct of place identity has developed within the literature on self and identity under the assumption that 'who we are' extends to, and is embedded within, the physical environments in which we live, work, and play. From this perspective, in a landmark paper on place identity, Proshansky, Fabian and Kaminoff (1983) define place identity as 'a substructure of the self-identity of the person consisting of, broadly conceived, cognitions about the physical world in which the individual lives' (p. 59). For Proshansky, Fabian and Kaminoff 'at the core of such physical environment-related cognitions is the 'environmental past' of the person; a past consisting of places, spaces and their properties which have served instrumentally in the satisfaction of the person's biological, psychological, social, and cultural needs' (p. 59). The past in this case refers to the history of an individual's person-place relations, but other authors have extended this to encapsulate the historical past of place, its heritage (e.g. Graham, Mason and Newman, 2009).

Within psychology, engagement with the local environment and its history has mostly been studied in terms of pro-social effects at an individual level. Indeed, Dixon and Durrheim (2000) argue that the majority of place identity research has paid little or no attention to the 'collective nature of the relations between persons, identities and material settings' (p. 29). Relatedly, engagement with the local environment has been explored in terms of its role in fostering place attachment (e.g. Manzo \& Perkins, 2006), defined as 'the bonding of people to places' (Low \& Altman, 1992, p. 2). However, whilst past research has shown that 'historical sites create a sense of continuity with the past, embody the group traditions, and 
facilitate place attachment' (Lewicka, 2008, p. 211), the majority of studies on attachment have focused on contemporary, rather than historical, aspects of the environment.

Moreover, the literature suggests that the local environment can be seen as an embodied form of a group's traditions, a physical expression of the group's culture and way of life (e.g. Osborne, 2001). The physical environment not only expresses and constructs one's individual level identity, but also the identity of a social group, or a community. We argue that if people construct - and dynamically change - their personal identities on the basis of the places they live in and the practices they engage in within those places, the same holds also for collective identities. In other words, places not only contribute to shaping the answer to the question 'Who am I?', but also help constructing an idea of 'Who we are' (see, e.g. Ashmore \& Knapp, 1999).

\section{Place-Based Social Identities}

Scholars have recognised the connection between place and social identity. For example, Bonaiuto, Breakwell and Cano (1996) showed how identity processes play an important role in predicting attitudes towards the local environment. While the direction of the relationship here is inverted (thus it is social identity predicting environmental attitudes), the evidence suggests that the physical environment is incorporated in one's own social identity. Evidence of the importance of place in constructing social identities is provided by Di Masso, Dixon and Pol (2011), who combined newspaper analysis and interview data to illustrate how communities discursively construct - and assign meanings to - places as part of their identity work in conflict situations.

The idea of place-based social identities (identitad social especial) was proposed by Valera and Pol (1994) as an extension of urban social identity (identitad social urbana,). Valera and Pol explain how the theoretical work in social psychology concerning social 
identity has often ignored the fact that the physical environment constitutes, itself, a source of social identity. The authors argue, for example, that information about the origin and whereabouts of an individual constitute a social category we use to inform our interactions with them and that the individuals themselves use as an element of their identity.

Our study takes this a step further by examining whether physically engaging with the environment (and its history) through community archaeology informs social identities rooted in place.

While most of the studies examining the relationship between heritage and place identity have been conducted in contexts where the individual engages with the environment when membership of the local community (i.e. collective identity) is not salient (see Twigger-Ross \& Uzzell, 1996, for a review), participating in community archaeological excavations with other volunteers from the local area should facilitate the emergence and/or salience of a group-based place identity. Participating in community based initiatives aimed at rediscovering heritage sites may constitute a bridge between the past and the future, as well as a bridge between 'me' and 'us'. It is therefore possible that learning about the past while participating in archaeological digs, volunteers would bring their historical group-based identities into their present practices, while sharing this experience with fellow community members. As a consequence, one could expect the emergence or reinforcement of placebased social identities, where beliefs and feelings about the local community are rooted in the places and spaces people inhabit. Importantly, Valera and Pol (1994) stress how urban social identities are characterised by the same socio-psychological processes as other, more traditional, social identities. As a consequence of the emergence of place-based social identities, we would therefore also expect to observe group processes at play when volunteers interact with each other and with other community members. 
To summarise, our study aimed to explore identity processes involved in participation in community-based archaeological initiatives. In particular, we were interested in whether and how the participation in the dig had an impact on the volunteers' identification with, and attachment to, the local area and community.

\section{Method}

\subsection{Study Context}

The Dig Greater Manchester initiative is a four-year project run by the Centre for Applied Archaeology (CFAA) at the University of Salford (UK) and the Association of Greater Manchester Authorities (UK). It encourages local communities to get involved with the history and heritage of their locale in a 'hands on' way. By inviting members of the community to actively participate in an archaeological excavation in their local areas, Dig Greater Manchester presents a unique opportunity to explore the role of community-based initiatives in fostering a identification with local community through an exploration of their shared history and heritage.

\subsection{Research Design}

Five focus groups were carried out in different dig locations: Radcliffe, Manchester, Salford, Stockport and Chadderton. Focus groups were held, where possible, in community spaces in the area where the digs had taken place to facilitate local participation. As the aim of the research was to understand a group of people's views on their local areas, focus groups were an appropriate method to generate group discussion. In addition, as the individuals participating in the focus groups already had shared experiences of dig participation, participants could use that common experience to foster discussion. In this sense, focus 
groups encouraged a more 'naturalistic' conversation (Braun \& Clarke, 2013). A topic guide was designed to guide the focus groups through the use of open questions (Arthur \& Nazroo, 2003; Krueger, 2009). Focus groups lasted between 50-60 minutes; they were audiorecorded, transcribed verbatim and anonymised for data analysis. The research adhered to the British Psychological Society’s (2009) Guidelines for Research in Psychology.

\subsection{Participants}

Participants were recruited via the University's database of Dig Greater Manchester volunteers and CFAA organised events such as workshops and open days. Twenty-four participants took part in one of five focus groups. Participants were selected to reflect the range of ages and occupational statuses and to ensure that the sample included participants of both genders.

[please insert Table 1 about here]

\subsection{Data analysis}

Data were analysed using a qualitative thematic analysis, following the procedure proposed by Braun and Clarke (2006). The thematic analysis was theoretically driven, thus the analysis focused on aspects of the conversations pertaining to the topics of interest. Analysis identified both semantic and latent meanings and processes underlying the content (Hsieh and Shannon, 2005). The researchers read the whole sample of transcripts repeatedly and identified themes which appeared to address the topics recurring in the focus groups and which were related to the key research questions. The head researcher then identified broader themes in which the set of sub-themes could fit. The researchers then re-coded the data on the basis of the agreed coding scheme. Ambiguous comments were discussed among coders, as were further suggestions for refining the coding scheme. A final coding scheme was then 
agreed, and coders re-coded the data on that basis. This led to the identification of a set of inclusive categories into which participants' comments were then coded. The analysis takes a critical realist stance (Clarke, Braun \& Hayfield, 2015), and as such aims to identify, through the language used by participants, the concepts and ideas that underpin the explicit content of the interviews.

\section{Analysis}

The analysis focuses on common themes identified in the data that highlight issues surrounding the development of place-based social identities and the emergence of groupbased processes in participants' experiences of dig participation. The first section addresses the process of establishing a group-based place identity; moving from 'I' to 'we'. The second section reports the social identity and group-based processes that were identified, where dig participation fostered positive interactions among members of local communities. Figure 1 summarises the themes and the sub-themes identified.

[Insert Figure 1 about here]

\subsection{Defining and evaluating membership - From 'I' to 'we'}

This theme revolves around the process of moving from an individual-level to a group-level place identity. The first sub-theme focuses on the definition and negotiation of belonging to the local area: by exploring the ways in which people articulate their identities as 'locals', the multifaceted aspects of 'localness' of place are explored. The second subtheme examines how participants give importance to their 'home' dig where place identities become particularly evident. The final sub-theme relates to how place identities are made in stories: during digs, participants shared and listened to stories concerning the past of the local area through which, a sense of shared place-based social identity emerged. 


\subsubsection{The complexity of being 'local' to the dig}

As part of the focus group interviews, participants were asked whether they would define themselves as local to the area where the dig was taking place. What it meant to be 'local' varied greatly among participants, which highlights the complexities and contested nature (Dixon \& Durrheim, 2000) of 'localness' and place identity.

CELIA I was born up the street and lived up the street. I went to the school here. I played here. I had this in my soul. It's through me like Blackpool rock. It's written through me. I was taught from knee high to a grasshopper that this is the centre of the universe. (LAUGHS) It is so old. This area is so old. I've had it sort of-I've had it drummed into me from being young that this is an exceptional area.

Celia portrays being 'local' as a deep-rooted connection to place, which is not only based on being 'born and bred' but on experiences; in other words, upon history. When place is portrayed as identity (e.g. 'it's written through me'), Celia belongs there. Furthermore, the longevity of the area's history gives a special status to place, which in turn enables Celia to claim a positive place identity. Celia's account of being 'local' is reinforced by Maddie's struggle to achieve a 'local' status (see below) due to being from elsewhere:

MADDIE: I obviously didn't grow up in England. I grew up in [foreign country] and I think, when I think about it, yes, I might be local, because I live here in Salford. But there is another thing that you've got to think about and that's that home feeling like, this is where my roots are. This is where my ancestors lived. This is - I had that thing with [foreign country] and I unfortunately don't have it with Salford. I met a lot of people who did and a lot of people who walked past the fences and asked so many questions and in that way I would say, no, I'm not local to the area, because I don't have that' INT: How would you describe yourself towards the area?

MADDIE: I live here. I'm getting to know the area and I'm getting to know the history of the area, which is great. But unfortunately not local.

CINDY:But Manchester and Salford are cities of incomers. I'm an incomer. You are an incomer

JOHN: I was born in [foreign country] and I came in in the early 60s. That generation after Wind Rush, when they were bringing folks in from the Commonwealth, because so many people had died in the Second World War. So my parents, we came up here from [foreign country]. Back then it was still 
obviously part of the empire. So yes, I've grown up and so I started my education out on the island and completed it here. But I've lived in the Manchester area pretty much all the time I've been here some 50 odd years. It's been, it's home.

The extract shows how those who are not 'born and bred' work harder for their right to belong as 'locals'. In other words, as Dixon and Durrheim (2000) note, identities, including those of being 'local', are not simply cognitive entities but rather are constructed through the language that participants use. Thus, we see that when Maddie seems uncertain that she 'might be local', Cindy provides a strategy for belonging by categorising the local area as 'cities of incomers'. In doing so, she claims 'localness' for herself and Maddie. Therefore, place identities here are collectively made and remade in talk (Dixon \& Durrheim, 2000; Di Masso, Dixon \& Pol, 2011). Similarly, John - another incomer - calls the area 'home' based on his long residence in place and the historical migration patterns that influenced his being there.

To summarise, the complexity of defining one's identity in relation to a place depends how each individual interprets 'belonging'. Participants were aware that 'being local' entails a deep-rooted sense of belonging to place, a connection that goes back generations. Yet in the absence of generational connections, others can define themselves as 'local' through alternative representations of place (as a place of incomers) or by portraying 'localness' as something that can be gained over time. The importance of time for place identity was effectively illustrated by Lalli (1988), who demonstrated how residents of an urban area who were born there identified more with the area on average when compared to people who were born elsewhere. This difference however decreased with increasing length of residence, until it became insignificant after decades. Likewise, Valera and Pol (1994) stress the necessity of considering the 'historical and temporal dimension when studying the relationship between individuals and their surroundings' (p. 20, author translation). In the extract above, participants find 'shortcuts' to claim they belong in the absence of time. 


\subsubsection{The 'Home Dig'}

Most participants took part in several digs organised by Dig Greater Manchester.

Nonetheless, whether by birth or by 'adoption', participants could identify a 'local' or 'home dig' i.e. the dig in closest proximity to their place of residence. The following extract illustrates that the complexities around claiming 'localness' continue here in the identification of a 'home dig':

INT: When you were doing it[the dig], did you see yourself as a local to the area, really?

DAVE: Yes, I would say, I'm from Manchester and I'm Mancunian. I was quite surprised with how close it [the dig] was to the city centre. I got the bus out of the city centre. I was looking for like, I always am. Before I go on a dig, because like some places are a bit further away, I'd always Google map and look for a landmark to look for the bus stop and stuff. I was quite surprised how close it was just leaving - I think it was off Deansgate. I would describe myself local. I'm from Tameside and that's the next dig in March. That is my local one.

INT: You do think of yourself as local.

DAVE It's all the same, it's Greater Manchester.

INT What about yourself?

MARILYN I'm a bit like DAVE. I live in Chorlton so my home dig, if you like would be Hulme. I've dug on many of the digs. I used to live next door to Bewell Hill Park and so that was a particular interest[.....]

INT When you were digging on the Manchester and that, did you think of yourself as local?

MARILYN Absolutely, yes. I live two miles away from that dig. It was really my home dig and it was very important to me that I dug in that one.

INT Why was it important that you dug in your home one?

MARILYN It's a connection with where I live and the history of where I live. Although I wasn't born and bred in Manchester, I've been in the area since the 70 s.

Dave navigates locality by adopting a superordinate category ('It's all the same, it's Greater Manchester') yet simultaneously identifies two local 'home digs', one close to his current residence and one where he considers himself to be from (Tameside). The 'born and bred' narrative plays out here as his place of birth makes another dig local to him. Marilyn further cements the concept of a 'home dig' by taking a 'particular interest' in the dig located 
where she has lived for a long time, although notably, she was not 'born and bred' there.

Indeed, participating in the dig offers a 'way in' for those from elsewhere:

ANDREW: We moved here about ten years ago, but I've been a constantly moving person. I moved to America. I moved to Scotland. I've been going all over the place. When I came onto this dig I was like, right, and noticed the Tower once in passing, but never actually had the time to come and have a look at it. In doing so I was like, oh, actually did the dig in the Tower with you. It was like oh. It was quite interesting. [Another volunteer] told me all about the history and stuff. Another one saying, when you meet people on the digs, learn about my own local history was quite interesting.

For Andrew, dig participation offered a sense of ownership to place ('my own local history'), as if the interactions with locals - who shared with him knowledge and awareness of the historical roots of the area - would allow him to belong there. Andrew makes sense of his interest in local history and participation in local digs by contrasting with his previously 'moving' lifestyle. As he has lived in his current locale for around a decade, history and heritage become more salient to him given his increased permanency in place over time (e.g. Lalli, 1988). This excerpt also indicates relations between people, and the local heritage stories that they share with one another are a vehicle through which 'localness' and placebased social identities are made and claimed (Dixon \& Durrheim, 2000).

\subsubsection{The importance of stories}

Volunteers reported frequently sharing memories and listening to others' stories about the local area during the excavations, which created 'social memories' of the history of place. Through storytelling, volunteers developed strong connections not only to the place but also to the local community:

JO You find that on a lot of the digs though, you find some members of the like older generation or a different generation to yourself, they do actually remember it. Even if they only just remember 'oh there used to be some walls in them bushes I wonder what they were' and you do get that sort of social memory coming out, they'll say 'Oh we used to go collecting conkers up 
there' or 'we used to play up there' and so that sorts of brings it to light in a sort of different facet as well.

JOHN $[\ldots]$ there is sharing very intimate part of their lives and they are telling you about people that you've never met. They are talking about the lives of three or four generations ago and as you say, that, inevitably brings a closeness that wasn't a deeper intimacy to relationships that were maybe at arm's length before. And fascinating, as I said earlier, watching people talking who you've never spoken to each other before, yet they live in the same street and so on. Definitely you were getting what I would call a closer intimacy into, with the folks around, because people were now sharing parts of their lives with you.

Digs made conversations about the history of place more possible, which appears particularly important for people from older generations. John's repeated use of 'intimacy' portrays how the sharing of stories were meaningful acts, allowing for a sense of closeness to grow within the community. Through sharing stories, practices, and physical spaces, shared social identities emerged for participants:

CELIA [talking about how the dig has impacted her view of the local community] I did meet more locals, just being around and doing the research as well as the digging. I found that, without exception, they were all interested in the area, in the history of the area and that they all had a nugget of information to pass on. The one thing that really struck home to me this dig was that this park what I've always held in a high place because it's a lovely park, really is the centre of this community. This is really a meeting place for lots of different minds and not bodies, minds. They all have an association with sort of within a few miles what I would class as being the local community. They all congregate here for all sorts of reasons. I never really took on board how important this park is. [...]

CELIA [talking about the experience of digging with others] you can feel, that's my wall. (LAUGHS) and it's not my wall. It's sort of our wall.

Interaction extended beyond the group of volunteers to other locals who were asking about what was going on there. Being in the park, digging and interacting with others, Celia realised the important of that shared local place as the 'centre of the community'. As a consequence, the heritage of place belongs not only to her but also to the whole community. Notably, in talking about experiences of digging with others, Celia hedges a claim of ownership over the wall. However, in doing so Celia moves from using 'my' (an individual 
level of categorisation) to 'our' (a group level of categorisation).

Participating in community archaeology, especially in the local area, therefore seems to encourage connection to the local area as well as a sense of community and shared place identity. Stories and the interaction with other members of the community offering (and requesting) information played a key role in this process. The notion that storytelling and dialogue can construct place identity, and potentially allow individuals to construct a sense of locatedness is found elsewhere (Dixon \& Durrheim, 2000; see also Gutting, 1996; Tuan, 1991) However, what we found in the archaeological digs is that exploring local history and interacting with fellow volunteers as well as members of the community facilitated the emergence of a group-based place identity, and thus moved from ' $\mathrm{I}$ ' to 'We' in place.

\subsection{Social Identity in action: intergroup processes}

According to social identity theory (Tajfel \& Turner, 1979) the development of a social identity brings to life several inter-group phenomena: by identifying as a member of a certain group, one is almost automatically identifying 'others'. One of the basic processes illustrated by Tajfel and Wilkes (1963) is that categorisation leads to the accentuation of similarities among members of the same categorical groups and of the differences between members of different categories. This process of social comparison is at the basis of most intergroup phenomena explored in group processes (see, e.g. Brown, 2000). Valera and Pol (1994) propose that the same processes underlie place-based social identities. Thus, if participation in digs facilitates or strengthens place-based social identity, it would follow that intergroup phenomena also take place. The following section explores participants' talk around inter-group aspects of participation in local digs, which appears to foster positive intergroup relations in several ways: challenging stereotypes, promoting a common identity, and guaranteeing an optimal level of distinctiveness for local identities of place. 


\subsubsection{Reconstructing others' social identities: challenging stereotypes}

Like other types of social identities, place-based social identities are characterised by sets of stereotypes (see, e.g. Tajfel, 1981). In other words, people sharing a common placebased identity are believed to share some similar characteristics (Valera and Pol, 1994; Valera, Guardia and Pol, 1998). Participants reported that digs challenged prevalent stereotypes associated with certain places through the opportunity to discover new local 'realities'. The following extract concerns Salford, which is historically known as an area of deprivation with high levels of criminality:

ANN I think, the Buile Hill Park one, when Mum and I were in a trench quite close to the fence, some people were walking past on the pathway, it was actually surprising how many people not just stopped but then asked what we were doing but then wanted to know more about what there was there and so we were sort of, well we weren't making things up but we informed them but we felt quite important

\section{ALL LAUGH}

ANN so it was nice and you know it wasn't just what are you doing and off they'd go it was yes they're actually interested and maybe you know you try not to make stereotypes and maybe sometimes you think oh that is surprising INT Do you think you did hold stereotypes of people in that community beforehand?

ANN I don't know

To Ann's surprise, local community members were interested in the dig, which

challenged her existing stereotypes of local community members who would not be interested in heritage of place and archaeological work. Likewise, a stroll to the local pub during a dig in Radcliffe allowed Andrew to change his mind about the local community there:

ANDREW ...[I] found they weren't pompous, rich people round that area. All the footballers live down there. They weren't, actually they were like everyday normal working class people. I was like right, they are not really posh. Can have a pint with them. It did actually change my perspective of like the local community round there - and the pubs. 
These changed perceptions of local community members support intergroup relations theories suggesting that contact among members of different groups who hold negative views of each other can lead to improved intergroup relations (e.g. Brown \& Hewstone, 2005; Pettigrew \& Troop, 2006). Participating in the shared activities of archaeological digs generates contact opportunities between different groups, which participants reported as changing their perceptions of communities in place.

\subsubsection{Negotiating social identities:}

By taking part in digs, participants came together with other volunteers from different local areas through their shared interest and purpose. Therefore, people with different place identities (i.e. related to specific suburbs, or groups of streets) potentially came to see themselves as having a common identity of place:

LUKE Chadderton is in three wards, in Chadderton North where the dig was, there's probably 10 or 12 or more distinct communities who identify themselves as living in Herald Green or Chadderton Fold, Bear trees, Park estate you know Cathedral Road area and they think we are all right here and the rest are terrible so it's about coming together and for me there were people from everywhere

As Luke suggests, people in the area of Chadderton do not necessarily identify as all living in the same area, and there can potentially be tensions between different hyperlocal realities. This is in line with the theoretical model proposed by Valera and Pol, which proposes that - like social identities in Turner et al.'s (1987) self categorisation theory - urban identities work at different levels of abstraction, from 'home' to 'neighbourhood', to metropolitan area, to city, and so on. Furthermore, and in line with Dixon and Durrheim's (2000) claim concerning the inherent political construction of place identities, Luke identifies how the different micro communities can situate themselves as in-groups and out-groups via negative stereotypes of the other. The dig meant that local people from the micro- 
communities came together, thus finding some common ground. What Luke describes fits into the common ingroup identity model (Gaertner, Dovidio, Anastasio, Bachman \& Rust, 1993), which proposes that intergroup relations can be improved by encouraging groups to think of themselves as members of more inclusive, superordinate categories.

The benefit of recategorisation into common superordinate categories can be observed not only in terms of bringing members of various local communities together: dig volunteers also reported positive interactions with people from different ethnic groups. For example, Marina reports how the dig successfully engaged some members from local Asian communities:

MARINA But there was interest from the Asian community as well quite a few families came

INT Was that surprising for you?

MARINA Yes because we had been trying to get them into the park for a long long while but they did.. I mean there weren't a lot but there were a few that came you know there was an interest there.

While she mitigates the extent of their involvement ('I mean, there weren't a lot'), raising their involvement alone suggests that the presence of an archaeological dig exploring common local heritage brought people together in a way that previous attempts had not. The dig, therefore, allowed members of local communities to find some commonality. The common ingroup identity model suggests that groups should be encouraged to think of themselves as part of a larger, common group, and it appears that the digs - in a variety of ways - allow for members to engage more in their community and to start this process of developing some form of common ground.

\subsubsection{We are the same, but different: dual identity and optimal distinctiveness}

The risk with the common identity model is that people feel their 'original' identity is being overlooked or denied. Local place identities risk being swallowed by superordinate 
categories (e.g. Greater Manchester). The dual identity model (Dovidio, Gaertner and Validsic, 1998) argues that one strategy would be to recognise an overarching shared identity while also maintaining a less inclusive, more specific one. In this way, harmonious relations between groups can be promoted.

While the digs promote a common identity, it is also evident that they allow for 'optimal distinctiveness' (Brewer, 1991) of more localised areas. As Jo describes below, within Greater Manchester there are a number of small local 'satellite' towns, which are often reported to rival each other in the struggle for distinctiveness:

JO [...] I think Stockport and some of the Greater Manchester cities and towns can be seen almost just as a satellite from Manchester and I think these local digs refocus it onto a local scale and you can see that actually there is a long history here and people from the community are actually getting their hands on that history and I think there is no better way to get an understanding and an appreciation of that

According to Jo, learning about local heritage through dig participation is a 'better' way to gain place distinctiveness, which can often be subsumed by the larger 'Greater Manchester' category. In this way, both the common identity of Greater Manchester and the more specific local identity (Stockport in Jo's case) can coexist and contribute to an individual's appreciation of the local area and nearby communities. The dual identity model supports Jo's argument in that the common identity of people from Stockport can be maintained, while also enabling the superordinate identity of 'Greater Manchester' to remain present and valued.

While the 'home dig' helps in the grounding of 'localness' to one's own place, participation in other digs allowed volunteers to gain a deeper appreciation of the heritage of nearby places:

MARINA I'd started with home, my home town which isn't my original hometown but Royton and then I'd heard you speak [another participant] he'd 
come and spoken at our history society about the hall and about the lake and all the rest of it and then to get the opportunity to go and do the dig I realised that Royton and Chadderton have got a lot in common you know so like you're saying it's nice to know that you're Royton or you're Chadderton but it's nice to know that there's common ground as well and that there's Royton Hall, Chadderton Hall and its OK to be the same but different. You know there's nothing wrong in taking a big pride in Chadderton and taking a big pride in Royton

Marina explicitly states 'it's okay to be the same but different', which directly supports the dual identity model and the optimal distinctiveness theory (Brewer, 1991). Chadderton and Royton are different areas, but as Marina says, they have common ground. For Marina, the dig allowed for the exploration of the individual stories and the heritage associated with various local areas. In other words, the dig offered the opportunity to find common ground among different sites while also guaranteeing a distinctive identity to each local reality.

To conclude, participating in the digs encouraged a positive place-related social identity, that is: through working in the local area and interacting with other local members of the community, sharing stories and coming in contact with a variety of people in the broader local context, people articulate and define a sense of 'we' (i.e. the local community). This, in turn results in a greater respect for the local community and the shared spaces, as Jo describes below:

JO And I think it can breed almost like a respect, a greater respect for the community, and the place that they live and the place that they use. I mean a lot of these places are parks or places where people walk their dogs or its wasteland so there is probably some quite seedy stuff goes on in some of those and some quite naughty stuff goes on LAUGHS in these spaces but I think you know, I if they are involved in something like this [...], it can really change the local community's attitude towards the space as it is when it is put back $[\ldots .$. 


\section{Conclusion}

This research has highlighted how community archaeological digs bring about intergroup dynamics that can be accounted for by adopting a social identity based approach to understanding intergroup relations. As such, this paper bridges the theoretical work of place based social identity (Valera \& Pol, 1994) and the political and symbolic dimensions of place identity (Dixon \& Durrheim, 2000).

Insights from the focus groups suggest that the boundaries of place and what it means to be 'local' are continuously negotiated. By participating in the dig, participants moved from the personal to a more social (community based) account of local history and heritage. Digs create opportunities for place-based history and heritage storytelling, which facilitated connections to both place and community. This in turn enabled participants to move from 'my' place to 'our' place. At the personal level, people might not strongly identify with the local area but by interacting with other members of the community and learning about local heritage, they can establish a sense of belonging. Participants also emphasised the importance of the 'home dig', illustrating how heritage in place can strengthen an individual's connection to community through the emergence of place-based social identities.

It is important to acknowledge that the findings here represent the voices of dig volunteers who have a vested interest in archaeological digs in their local areas, often at more than one site. If we take the position that talk is action orientated (Dixon \& Durrheim, 2000), what participants said about community digs is located within, and dependent upon their participation in community digs. Further research could therefore explore the perspectives of those living close to dig sites but who chose not to volunteer in the digs directly. Further research could also determine if participation in community archaeological projects is perceived as available to all. This would enable a wider understanding of the importance of 
heritage for a wider range of people who reside where community archaeological projects take place.

Identity in relation to place remains salient within contemporary times of greater movement, mobility, and migration patterns. Shared community activities provide opportunities for 'locals' and 'incomers' to weave themselves into place and gain a sense of belonging. Archaeological digs enhance this through a focus on heritage and the environmental past of place as relevant to the present. Many intergroup conflicts arise from territorial issues and community archaeology may offer ways to shape intergroup relations through a shared exploration of the past. As such, local authorities, community organisations and governments should seek to support community archaeology initiatives to strengthen ties to place and manage existing and emerging intergroup relations within local communities.

\section{References}

Ashmore, W. and Knapp, A. B. (Eds.) (1999). Archaeologies of landscape: contemporary perspectives. Oxford: Blackwell.

Arthur, S., \& Nazroo, J. (2003). Designing fieldwork strategies and materials. In J. Ritchie \& J. Lewis (eds). Qualitative research practice: A guide for social science students and researchers. (pp. 109-137). London: Sage.

Bonaiuto, M., Breakwell, G. M., \& Cano, I. (1996). Identity processes and environmental threat: The effects of nationalism and local identity upon perception of beach pollution. Journal of Community \& Applied Social Psychology, 6(3), 157-175.

Braun, V., \& Clarke, V. (2006). Using thematic analysis in psychology. Qualitative Research in Psychology, 3(2), 77-101. 
Braun, V. \& Clarke, V. (2013). Successful qualitative research: A practical guide for beginners. London: Sage Publications.

Brewer, M. B. (1991). The social self: On being the same and different at the same time. Personality and Social Psychology Bulletin, 17(5), 475-482.

British Psychological Society (2009) Code of Human research Ethics. Available online at: http://www.bps.org.uk/sites/default/files/documents/code_of_human_research_ethics. pdf [Accessed Jan, 11 2013]

Brown, R. (2000). Group Processes: Dynamics within and Between Groups. London: Wyley.

Brown, R., \& Hewstone, M. (2005). An integrative theory of intergroup contact. Advances in Experimental Social Psychology, 37, 255-343.

Chirikure, S., \& Pwiti, G. (2008). Community involvement in archaeology and cultural heritage management. Current Anthropology, 49(3), 467-485.

Clarke, V., Braun, V., \& Hayfield, N. (2015). Thematic analysis. In J.A.Smith (ed). Qualitative Psychology: A practical guide to research methods ( $3^{\text {rd }}$ edition). (pp. 222248). London: Sage Publications.

Di Masso, A., Dixon, J., \& Pol, E. (2011). On the contested nature of place:'Figuera's Well', 'The Hole of Shame'and the ideological struggle over public space in Barcelona. Journal of environmental psychology, 31(3), 231-244.

Dixon, J., \& Durrheim, K. (2000). Displacing place-identity: a discursive approach to locating self and other. British journal of social psychology, 39(1), 27-44.

Dovidio, J. F., Gaertner, S. L., \& Validzic, A. (1998). Intergroup bias: status, differentiation, and a common in-group identity. Journal of Personality and Social Psychology, 75(1), 109-120. 
Gaertner, S. L., Dovidio, J. F., Anastasio, P. A., Bachman, B. A., \& Rust, M. C. (1993). The Common Ingroup Identity Model: Recategorization and the reduction of intergroup bias. European Review of Social Psychology, 4, 1-26.

Graham, H., Mason, R., \& Newman, A. (2009). Historic environment, sense of place, and social capital. Available online at http://eprints.soton.ac.uk/182155/1/Historic_Environment,_Sense_of_Place_and_Soci al_Capital_Lit_Review.pdf [retrieved 23/06/2014]

Gutting, D. (1996). Narative identity and residential history. Area, 28, 482-490.

Hsieh, H. F., \& Shannon, S. E. (2005). Three approaches to qualitative content analysis. Qualitative Health Research, 15(9), 1277-1288.

Krueger, R. A. (2009). Focus groups: A practical guide for applied research. London: Sage.

Lalli, M. (1988). Urban identity. In Environmental social psychology (pp. 303-311). Springer Netherlands.

Lewicka, M. (2008). Place attachment, place identity, and place memory: Restoring the forgotten city past. Journal of Environmental Psychology, 28(3), 209-231.

Low, S. M., \& Altman, I. (1992). Place attachment: A conceptual enquiry. In: I. Altman and S.M. Low (eds) Place attachment (pp. 1-12). New York: Premium Press.

Manzo, L. C., \& Perkins, D. D. (2006). Finding common ground: The importance of place attachment to community participation and planning. Journal of Planning Literature, 20(4), 335-350.

McGimsey, C. R., III. (1972). Public archaeology. New York: Seminar Press.

Osborne, B.S. (2001) Landscapes, Memory, Monuments, and Commemoration: Putting Identity in Its Place. Available online at: http://www.metropolis.net/ [Accessed Jan $11,2013]$

Pettigrew, T. F., \& Tropp, L. R. (2006). A meta-analytic test of intergroup contact theory. Journal of Personality and Social Psychology, 90(5), 751. 
Proshansky, H. M., Fabian, A. K., \& Kaminoff, R. (1983). Place-identity: Physical world socialization of the self. Journal of environmental psychology, 3(1), 57-83.

Tajfel, H. (1981). Human groups and social categories: Studies in social psychology. CUP Archive.

Tajfel, H., \& Turner, J. C. (1979). An integrative theory of intergroup conflict. The Social Psychology of Intergroup Relations, 33(47), 74.

Tajfel, H., \& Wilkes, A.L. (1963). Classification and quantitative judgment. British Journal of Psychology, 54, 101-1 14.

Tuan, Y.F. (1991). Language and the making of place: A narrative-descriptive approach. Annals of the Association of American Geographers, 81, 684-696.

Turner, J. C., Hogg, M. A., Oakes, P. J., Reicher, S. D., \& Wetherell, M. S. (1987). Rediscovering the social group: A self-categorization theory. Basil Blackwell.

Twigger-Ross, C. L., \& Uzzell, D. L. (1996). Place and identity processes. Journal of Environmental Psychology, 16(3), 205-220.

Valera, S., \& Pol, E. (1994). El concepto de identidad social urbana: una aproximación entre la psicología social y la psicología ambiental. Anuario de psicología/The UB Journal of psychology, (62), 5-24.

Valera, S., Guàrdia, J., \& Pol, E. (1998). A study of the symbolic aspects of space using nonquantitative techniques of analysis. Quality and Quantity,32(4), 367-381.

Wilkinson, S. (2015). Focus groups. In J.A.Smith (ed). Qualitative Psychology: A practical guide to research methods ( $3^{\text {rd }}$ edition). (pp. 199-221). London: Sage Publications. 
Table 1 Sample characteristics

\begin{tabular}{|c|c|c|c|c|}
\hline $\begin{array}{l}\text { Focus Group } \\
\text { Location }\end{array}$ & $\begin{array}{l}\text { Participants } \\
\text { N }\end{array}$ & Age & Gender & Occupational status \\
\hline \multirow{6}{*}{ Radcliffe } & \multirow[t]{6}{*}{ 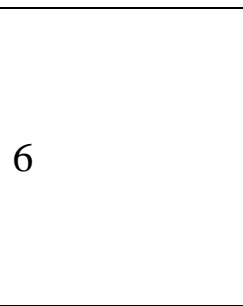 } & $17-25$ & $\mathrm{M}$ & Student \\
\hline & & $17-25$ & $\mathrm{~F}$ & Student \\
\hline & & $41-60$ & $\mathrm{M}$ & Employed \\
\hline & & $61-80$ & $\mathrm{M}$ & Retired \\
\hline & & $61-80$ & $\mathrm{~F}$ & Retired \\
\hline & & $61-80$ & $\mathrm{M}$ & Retired \\
\hline \multirow{4}{*}{ Manchester } & \multirow{4}{*}{4} & $17-25$ & $\mathrm{M}$ & Student \\
\hline & & $61-80$ & $\mathrm{~F}$ & Retired \\
\hline & & $61-80$ & $\mathrm{~F}$ & Retired \\
\hline & & $61-80$ & $\mathrm{M}$ & Employed \\
\hline \multirow{4}{*}{ Salford } & \multirow{4}{*}{4} & $17-25$ & $\mathrm{~F}$ & Student \\
\hline & & $41-60$ & $\mathrm{~F}$ & P/t Employed \\
\hline & & $61-80$ & $\mathrm{M}$ & P/t Employed \\
\hline & & $61-80$ & $\mathrm{M}$ & Retired \\
\hline \multirow{5}{*}{ Stockport } & \multirow{5}{*}{5} & $26-40$ & $\mathrm{~F}$ & Employed \\
\hline & & $41-60$ & $\mathrm{~F}$ & Employed \\
\hline & & $41-60$ & $\mathrm{M}$ & Employed \\
\hline & & $41-60$ & $\mathrm{~F}$ & Student \\
\hline & & $61-80$ & $\mathrm{~F}$ & retired \\
\hline \multirow{5}{*}{ Chadderton } & \multirow{5}{*}{5} & $41-60$ & $\mathrm{~F}$ & Employed \\
\hline & & $41-60$ & $\mathrm{~F}$ & P/t employed \\
\hline & & $41-60$ & $\mathrm{M}$ & Retired \\
\hline & & $61-80$ & $\mathrm{M}$ & Retired \\
\hline & & $61-80$ & $\mathrm{~F}$ & Retired \\
\hline
\end{tabular}


Defining and evaluating membership: from 'I' to 'we'

- The complexity of 'being local' to the dig

- The 'Home dig'

- The importance of stories
Social identity in action:

group processes

- Challenging stereotypes

- Common identity

- Dual Identity and optimal distinctiveness

Figure 1 Key themes identified in the analysis 